\title{
Financial Performance of the Local Government Institution (Case Study of DKI Jakarta Province)
}

\author{
Andy Prasetiawan Hamzah ${ }^{1}$, Swarmilah Hariani ${ }^{2}$, Fadlil Usman ${ }^{3}$ \\ 1,3 State Finance Polytechnic STAN \\ ${ }^{2}$ Universitas Mercu Buana
}

\begin{abstract}
This study aims to prove the effect of the implications of Budgeting Participation, Clarity of Budget Objectives, Public Accountability on the Financial Performance of Local Government (Empirical Study in DKI Jakarta Province) The object of this research is 15 OPD (Regional Organization) with 62 questionnaires in the DKI Jakarta Provincial Government. The results of this study indicate that budgetary participation does not affect the performance of local government. This means that the increase or decrease in budget participation will not have a significant impact on the performance of local government. Clarity of Budget Objectives and Public Accountability affect the Financial Performance of the Local Government. This means that all budget goals that have been made will have an impact on increasing or decreasing performance. The clearer the clarity of the budget goals in the preparation of the budget, the higher the performance of local government and conversely. Seen from public accountability in the local government making information received by the public more balanced, which means that information asymmetry that occurs can be reduced.

Keywords: Financial Performance of Local Government, Budget Participation, Clarity of Budget Objectives, and Public Accountability
\end{abstract}

DOI: $10.7176 / \mathrm{DCS} / 9-2-07$

\section{Introduction}

Budget becomes very important instrument in conducting the effective short-term planning and controlling to an organization (Anthony and Govindarajan, 2001). Budget is needed in conducting planning and controlling in order to reach the goal of an organization, including government organizations or public sectors.

Audit Board of the Republic of Indonesia declare that this factor influences the quality of financial reporting in the local government, namely an internal control system that improves the Performance of Local Government (www.bpk.go.id). The results of the examination of Audit Board of the Republic of Indonesia (BPK RI) in the 2017 Examination Summary revealed that the internal control system for the management and accountability of 2017 regional revenues has not been fully adequate and there is still non-compliance with statutory provisions. The conclusion is based on weaknesses in internal control and compliance with laws and regulations. Weaknesses in internal control systems such as the Weakness of the Accounting and Reporting Control System, Weaknesses of the Implementation Control System of the Revenue and Expenditure Budget and the Weakness of the Internal Control Structure.

The result of BPK RI's examination on Laporan Kinerja Pemerintahan Daerah (LKPD) shows that the administration is not as expected. There is no unqualified opinion from the BPK which shows that the financial reporting of local governments is not fully justified by the BPK, due to a weak internal control system, regional wealth has not been well organized; The implementation of the procurement of goods and services is not in accordance with the applicable law; d) Presentation of financial statements not in accordance with Government Accounting Standards and Weaknesses in the financial reporting system (www.bpk.go.id).

The information contained in the Regional Government Financial Statements must be useful and appropriate for the needs of stakeholders, free from misstatements of information that can mislead users of financial statements (Hari, 2013; Nurlis, 2018). Finance Reports produced by the local government will be used by several parties as a basis for decision making. In 2017 Semester Examination Results Summary (IHPS) One of the problems that underlies the Regional Government Financial Statements that do not get a Fair Unqualified opinion from the audit board of the Republic of Indonesia, and is faced by many government agencies, both at the central and regional levels, is a scarce resource personnel who have sufficient competence to carry out regional financial administration. (Tandjung, 2013: 6). 
According to Damrongsukniwat (2015) Budgeting is the management foundation in financial planning which is used as the basis for financial control for the future period. Planning and control processes in the organization and are widely used, far from perfect. An organization uses a budget for performance evaluation (Hansen, and Mowen, 2005. Budget allowances create budget bias so that it can reduce profits due to expensive planning errors and greater compensation or additional consumption for subordinates. Through the presence of budget participation, interaction can be seen. between employees and their superiors, because of this, employees can carry out the necessary activities ranging from budget preparation, negotiation, final budgeting, and revision of the necessary budget (Etemadi and Sirghani, 2016). Budget participation is needed, this can be made according with existing reality in the field, in budgeting participation, collaboration between supervisors and subordinates Sundari et all (2016).

Clarity of the budget target is the extent to which the budget target is clearly and specifically set with the aim that the budget can be understood by people responsible for achieving budget targets (Kewo, 2014). Clarity of budget goals can improve the performance of individuals and organizations. Clarity of budget goals is intended to increase the responsibility of individuals and organizations in achieving budget goals. So that the organization is expected to open up space and plan as well as possible in preparing its budget (Kenis, 1979). Clarity of budget targets will help local government officials to achieve expected performance. By knowing the budget goals, the budget is clear, easier to implement and accountable (success or failure). The ambiguity of the target budget will cause confusion in the implementation, not calm and not satisfied at work.

Public accountability is a complex and elusive concept. In different contexts different meanings can be present. Despite its complexity, accountability is an attractive term and many people from practitioners and academics often use politicians. In the modern era there is no argument about the need for accountability in any society in the whole world. Public accountability is even considered as one of the cornerstones of good governance (Sheehan, 1996). The 'publicness' of public relations is at least two different features. First of all, 'public' relates to openness. The account giving is done in public, i.e. it is open to at least accessible to citizens. Therefore, we will only take passing, often more informal, confidential, if not secret, forms of internal accountability. Secondly, 'public' refers to the public sector. We will concentrate on public managers, public spending, exercising public authority, or managing a corporate body under public law (Dubnick et al., 1993).

In the context of local government, the clarity of budget targets is also included in the Regional Strategic Plan and Regional Development Program. So that with clear clarity of budget targets, the budget executing apparatus will also be helpful in its realization, this will directly affect the performance of the apparatus. One of the causes of the ineffective and inefficient budget is due to the lack of clarity in the budget targets which have resulted in local government officials having difficulties in preparing budget targets.

\section{Theory and Hypothesis}

\subsection{Performance}

The Goal setting theory developed by Locke (1968) explains the relationship between goals set with work performance. From the opinion of the experts above it can be said that goal setting is a result-oriented target setting. In public sector organizations, the government seeks to achieve the goal of achieving optimal performance by involving lower and middle level managers in the preparation of the budget as a tool that is believed to increase the achievement of the objectives set.

Performance is a description of the level of achievement of an activity / program / policy in realizing the goals, objectives, mission, organizational vision contained in the strategic planning of an organization (Mahsum, 2006). According to Baird (1998); Hatry, (1999) performance measurement helps managers evaluate the performance of individuals, activities, projects and sectors and therefore helps make organizations accountable for their performance, performance is often used to refer to individual or group individual achievements or levels of success. Usual performance is known if the individual or group of individuals has a predetermined success criteria. This success criterion is in the form of certain goals to be achieved. Without organizational goals it is impossible to know the benchmarks of success and failure (Baird 1998). Through performance evaluation, arbitrary assessment and examining performance that helps improve quality and reduce the costs of government activities (Hatry, 1999). 
The list to be achieved is contained in the strategic planning of an organization (Indra, 2006). So that government performance can be understood as the level of achievement of organizational goals or the level of achievement of results in relation to tasks and functions charged to the organization, or it can also be concluded that performance is a degree to which the organization's activities reach the goal. Performance appraisal can be interpreted as a periodic determination of the operational effectiveness of an organization, organizational parts and employees based on predetermined targets, standards and performance (Mulyadi, 2001). To be able to find out whether the performance is effective / ineffective, a comparison must be made of the budget. The budget is the best starting point in assessing performance. The items in the budget allocation process and ensure that the unit cannot exceed the expenditure ceiling or upper limit (Shah and Shen, 2007).

\subsection{Budgeting Participation on Financial Performance of Local Government}

Participatory budgeting is expected to improve manager performance, namely when a goal is designed and agreed upon participation, employees will internalize the goals set and have a sense of personal responsibility to achieve them, because they are involved in budgeting (Milani, 1975). Budget participation requires the participation of more managers in the drafting process. Not only upper level managers, but also middle level managers and lower level managers.

Individual agency performance in managerial activities, planning, investigation, coordination, supervision, staffing, negotiation and refresentation, according to Mahoney et al (1963) management has important tasks such as planning, coordinating subordinate tasks, control and decision making. Management must give assignments to the subordinates, outline what is desired by management and stimulate them to jointly achieve management goals. Managerial performance obtained by managers is one of the factors that can be used to improve organizational effectiveness.

According to Hansen and Mowen (2004) Participation in the budgeting process is an involvement that includes giving opinions and proposals from subordinates to the leadership at the time of budgeting. Participation in question is a collaborative process of various parties, both subordinates and top level managers in decision makers who influence decision making in the future.

Broad participation is basically an organizational process, where the members of the organization are involved and have an influence on a decision making that has an interest in them. Participation in the context of budgeting is a process whereby individuals whose performance is evaluated and receives an award based on the achievement of the budget, is involved and has an influence in preparing budget targets (Brownell, 1982).

According to Cherrington (1995) there are three main objectives that can be achieved through participation in the budget, namely: 1) Acceptance of employees for planned company activities. 2) Increased morale. 3) Increased productivity. Participatory budgets lead to how much the individual engages in preparing the budget and its implementation to achieve the budget target. This is needed so that managers feel more satisfied and productive in their work, so that there will be feelings to always want to achieve.

The advantages of participatory budgeting are lower-level and middle-level managers who feel their opinions and views are valued by the leadership, so they are more motivated to reach the budget target. Budget estimates made by lower-level and middle-level managers will be more accurate and reliable than estimates made by leaders who are unaware of daily operations. By participating in the budgeting process, managers will be more motivated to achieve the budget targets that have been decided together. In addition, in the participatory budget there is a unique control system, that is, mistakes and responsibilities are found in the preparation of the budget itself, so that they cannot argue that budget targets will not be able to be achieved. Based: on the above can be developed hypothesis research description, H1: The Budget Participation has a positive and significant effect on the Financial Performance of Local Government. 


\subsection{Clarity of Budget Objectives on Financial Performance of Local Government}

The target according to Permendagri Number 13 of 2006 concerning Guidelines for Regional Financial Management is "the expected results of a program or output expected from an activity. Kenis (1979) states that the clarity of the budget target is the extent to which the objectives of the budget are clearly and specifically aimed at the budget can be understood by people who are responsible for achieving the budget goals. Clarity of the budget target will help the budget implementing apparatus in its realization. The ambiguity of the budget target will cause budget implementers to be confused and dissatisfied in their work.

Locke (1968) states that setting budget targets specifically is more productive than if there are no targets. This will encourage employees to be able to do their best. Budget gap is the action of subordinates who understate their productive capacity when subordinates are given the opportunity to determine their performance standards. This causes a difference between the budget reported and the budget that fits the best estimate for the organization.

Kennis (1979) in Putra (2013) explains that clarity of budget goals is the extent to which budget goals are clearly and specifically set with the aim that the budget can be understood by people responsible for achieving budget goals that is. Clarity of budget targets has implications for the apparatus to prepare budgets in accordance with the objectives of government agencies.

The success of the performance of a government agency is inseparable from the performance of the government apparatus in charge, the apparatus is required to have professionalism in accordance with their duties and positions (Mardiasmo, 2004). Carrying out each field of work in accordance with the tasks and functions structurally a credible organization becomes one of the duties and obligations of the position that must be carried out with trust and in accordance with existing regulations. Improving apparatus performance is one indicator of success in implementing the apparatus development program.

According to Herzberg (1959: 80) unclear goals cause doubts for managers in acting, because he does not know whether his actions lead to achieving goals. This manager's hesitation will certainly lead to dissatisfaction. The absence of job guarantees will cause dissatisfaction as expressed in the satisfaction theory. Based on the above can be developed hypothesis research description, H2: Clarity of Budget Objectives has a positive and significant effect on the Financial Performance of Local Government.

\subsection{Public Accountability on Financial Performance of Local Government}

Accountability is one of the pillars of good government which is the responsibility of the regional government in making a decision in the public interest, in this case as the responsibility of the regional government for the public services provided. According to Mardiasmo (2002: 20) The definition of public accountability is as follows: "Accountability is the obligation of the trustee to provide accountability, present, report and disclose all activities of activities which are his responsibility to the trustee who has the right and authority to hold such responsibility. "To create accountability to the public, the participation of heads of institutions and community members is needed budget preparation and supervision (Rubin, 1996).

Chandler and Piano (1982) define accountability as a reference to the institution of checks and balances in administrative systems. Accountability according to The Ox fond Advance. Leaner Dictionary (2000), interpreted as required or not to give explanation for one's action. For this reason, accountability is needed or expected to provide an explanation for what has been done by the bureaucracy, that accountability is a concept related to external standards that determine the correctness of an action by the public bureaucracy. The change in the paradigm of the budget in the reform era requires public participation in the entire budget cycle.

Peters (2010: 165) explains that accountability is a different concept of responsibility (responsibility). Accountability refers more to organizational relations as an entity with parties outside the organization. That is, the level of accountability analysis is at the macro organization level that emphasizes the sociological aspects of the organization with a focus on interactions between the organization and the parties that relate to the organization. While responsibility emphasizes on the individual level as a requirement for members in a public organization to show behavior that is in line with ethical standards that have been set as rules and carry out work correctly in accordance with the direction and training that has been received. Based on the above can be 
developed hypothesis research description, H3: Public Accountability has a positive and significant effect on the Financial Performance of Local Government.

\section{Research Methodology}

In this study, the tool used to collect primary data is a questionnaire. The object of this research is 15 OPDs (Regional Device Organizations) in the budget section of the DKI Jakarta Provincial OPD. OPD in the Provincial DKI Jakarta. This can be seen from the opinion of the BPK RI regarding LKPD given from 2012 to 2015 which is always an opinion that meets the requirements (IHPS BPK RI in the first semester 2017). Of the 67 questionnaires distributed, 62 questionnaires were returned and eligible.

\section{Result Analysis}

Tabel 1

Descriptive Statistics

\begin{tabular}{|c|c|c|c|c|c|}
\hline & N & Minimum & Maximum & Mean & Std. Deviation \\
\hline X1 & 62 & 17 & 25 & 20.74 & 2.032 \\
X2 & 62 & 16 & 20 & 17.77 & 1.583 \\
X3 & 62 & 15 & 20 & 16.87 & 1.604 \\
Y & 62 & 22 & 30 & 25.48 & 2.296 \\
Valid N (listwise) & 62 & & & & \\
\hline
\end{tabular}

Source: SPSS Processing Results, 2017

The multicollinearity test aims to test whether the regression model found a correlation between the independent variables. A good regression model should not have a correlation between independent variables. The cut off value commonly used to indicate the presence of multicollinearity is the Tolerance Value $\leq 0.10$ or equal to the VIF value $\geq 10$.

Tabel 2 Multicollinearity Test Results

\begin{tabular}{|c|c|c|c|c|c|c|c|c|}
\hline \multicolumn{9}{|c|}{ Coefficients $^{\mathrm{a}}$} \\
\hline & \multirow{2}{*}{ Model } & \multicolumn{2}{|c|}{ Unstandardized Coefficients } & \multirow{2}{*}{$\begin{array}{c}\text { Standardized } \\
\text { Coefficients }\end{array}$} & \multirow{2}{*}{$\mathbf{T}$} & \multirow{2}{*}{ Sig. } & \multicolumn{2}{|c|}{$\begin{array}{c}\text { Collinearity } \\
\text { Statistics }\end{array}$} \\
\hline & & B & Std. Error & & & & Tolerance & VIF \\
\hline \multirow[t]{4}{*}{1} & (Constant) & 2,083 & 2,888 & & ,721 & ,474 & & \\
\hline & $\mathrm{X} 1$ & , 146 & , 109 & , 129 & 1,346 & , 183 & ,833 & 1,201 \\
\hline & $\mathrm{X} 2$ & ,479 & , 138 & ,330 & 3,475 & 001 & ,851 & 1,175 \\
\hline & $\mathrm{X} 3$ & ,703 & , 142 & ,491 & 4,966 & ,000 & ,785 & 1,273 \\
\hline
\end{tabular}

Source: SPSS Processing Results, 2017

It shows that all independent variables from the six test models have a tolerance value greater than 0.10 and the VIF value is smaller or less than 10. So it can be concluded that the regression model does not occur multicolonity between independent variables. 
Figure 1: P-P Normality Test Plot

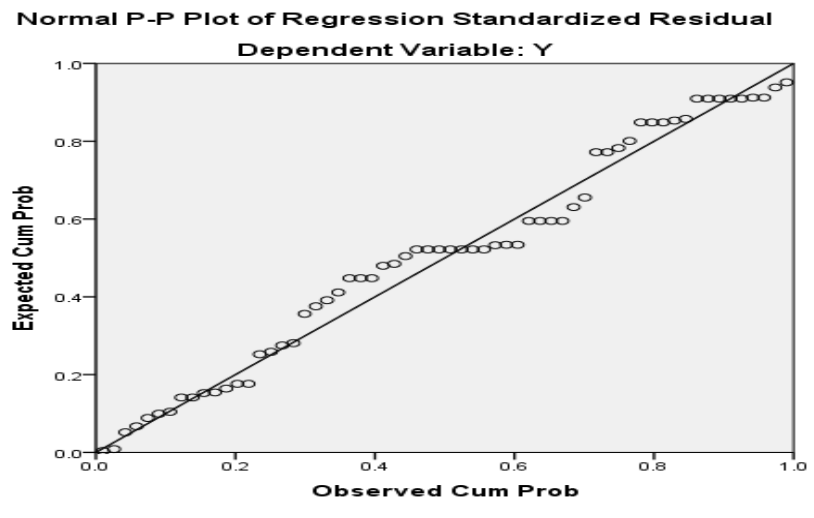

Graph

Source: SPSS Processing Results, 2017

Based on Figure 1 above shows the existence of dots (data) scattered around the diagonal line and the spread of these points follows the direction of the diagonal line. This means that the regression models in this study meet the normality assumption based on normal probability plot graph analysis.

Table 3: Glejser Test Results

\begin{tabular}{|c|c|c|c|c|c|c|}
\hline & \multirow{2}{*}{ Model } & \multicolumn{2}{|c|}{$\begin{array}{c}\text { Unstandardized } \\
\text { Coefficients }\end{array}$} & \multirow{2}{*}{$\begin{array}{c}\text { Standardized } \\
\text { Coefficients } \\
\text { Beta }\end{array}$} & \multirow{2}{*}{$\mathbf{T}$} & \multirow{2}{*}{ Sig. } \\
\hline & & B & $\begin{array}{l}\text { Std. } \\
\text { Error }\end{array}$ & & & \\
\hline \multirow[t]{4}{*}{1} & (Constant) & 2,083 & 2,888 & & 721 & 474 \\
\hline & $\mathrm{X} 1$ & 146 & 109, & 129, & 1,346 & 183, \\
\hline & $x 2$ & 479, & 138 & 330, & 3,475 & 001 \\
\hline & $x 3$ & 703 & 142 & 491 & 4,966 & 000 \\
\hline
\end{tabular}

Source: SPSS Processing Results, 2017

Based on the test results in the table above, it can be seen that there are no significant variables in the regression with the Absut variable. This can be seen from the level of significance greater than the alpha value of 0.05 so that it can be concluded that the regression model used in this study is free from heteroscedasticity.

Testing the coefficient of determination (R2) aims to see or measure how far the ability of the model in explaining the variation of the dependent variable. A small R2 value means the ability of independent variables to explain dependent variation is very limited. Values close to one mean that the independent variables provide almost all the information needed to predict variations in the dependent variable. The measurement value of the coefficient of determination can be seen in the amount of Adjusted R Square taken from the following summary model in table 5 . 
Table 4: Results of the Determination Coefficient (R2) Model Summaryb

\begin{tabular}{|c|c|c|c|c|}
\hline Model & $\mathbf{R}$ & $\begin{array}{c}\text { R } \\
\text { Square }\end{array}$ & $\begin{array}{c}\text { Adjusted } \\
\text { R Square }\end{array}$ & $\begin{array}{c}\text { Std. Error } \\
\text { of the } \\
\text { Estimate }\end{array}$ \\
\hline 1 & $.745^{\mathrm{a}}$ & .554 & .531 & 1.572 \\
\hline
\end{tabular}

Source: SPSS Processing Results, 2017

The amount of Adjusted R Square is 0.531. This indicates that the contribution of the variable budget participation, the clarity of the budget target, public accountability is equal to $53.1 \%$ while $46.9 \%$ is determined by other factors outside the model that are not detected in this study.

The F test is carried out with the aim of testing whether all the independent variables included in the model have a joint influence on the dependent variable. The F test uses the formula of degree of freedom (df). The $\mathrm{F}$ test is carried out with the aim of testing that has a joint influence on the dependent variable. The $\mathrm{F}$ test uses the formula of the degree of freedom (df).

Table 5 Simultaneous Significance Test Results (F Test) ANOVA $^{\mathrm{a}}$

\begin{tabular}{|c|c|c|c|c|c|c|}
\hline \multicolumn{2}{|c|}{ Model } & $\begin{array}{c}\text { Sum of } \\
\text { Squares }\end{array}$ & Df & $\begin{array}{c}\text { Mean } \\
\text { Square }\end{array}$ & F & Sig. \\
\hline 1 & Regression & 178.209 & 3 & 59.403 & 24.047 & $.000^{\mathrm{b}}$ \\
& Residual & 143.274 & 58 & 2.470 & & \\
& Total & 321.484 & 61 & & & \\
\hline
\end{tabular}

Source: SPSS Processing Results, 2017

The regression results show that Fcount is greater than Ftable which is 24.047> or a significant value of $0.000<\alpha$ 0.05. This indicates that the regression model can predict that the Effect of Budgetary Participation, Clarity of Budget Objectives, Public Accountability on the Performance of Local Government

This shows that budgetary participation does not have a significant positive effect on the performance of DKI Jakarta Provincial Government agencies. This means that the increase or decrease in budget participation will not have a significant impact on the performance of local government officials. This is consistent with the research conducted by Dwirianti (2015) in Pelalawan District, Polko (2015) in Poland, and Bassoli (2011) in Italy. The results of the study stated that there was no influence between budget participation on the performance of local governments. This means that the increase or decrease in budget participation will not have a significant impact on the performance of local government officials. This means that the decrease in the participation of local government officials in budgeting will also decrease the performance of regional government officials. This means that the involvement of local government officials in preparing the budget will not encourage the officials to be responsible for each of the tasks they carry out so that they cannot improve performance and the targets that have been set cannot be achieved.

The test results in the second hypothesis indicate that the clarity of the budget target has a positive and significant effect on the performance of the regional government agencies in DKI Jakarta province. This means that all budget targets that have been made will have an impact on increasing or decreasing performance. The clearer the clarity of the budget goals in the preparation of the budget, the higher the performance of local government agencies and vice versa. Thus Ho is rejected and Ha is accepted. The results of this study support the statement of Research Locke (1968); Kenis (1979) in Mawikere et al (2007). There are budget targets clear, it 
will make it easier to account for success or failure of the implementation of organizational tasks in order to achieve the objectives and targets that have been previously set.

In testing the third hypothesis, the hypothesis can be accepted. This shows that public accountability influences the performance of regional government agencies. Research conducted by Schillemans (2011) and Pollitt (2008) shows that public accountability has a significant positive effect on managerial performance. The DPRD will oversee the behavior of the government, the DPRD requires the government to account for the management of resources mandated by the government in assessing accountability through periodic financial reporting. This gives the implication that the importance of public accountability in improving managerial performance of local governments. Accountability assessments can be seen from the budgeting process starting from planning, arrangement, until implementation must be reported to the DPRD or the community. The community, in this case has the right to know the budgeting process and can demand accountability for the plan and implementation of the budget. That the performance management system will increase institutional accountability to the people and political representation.

\section{Conclusion}

Budget Preparation Participation does not affect the Performance of DKI Jakarta Provincial Government Agencies. This means that the increase or decrease in budget participation will not have a significant impact on the performance of local government officials. Clarity of budget targets has a positive and significant effect on the performance of regional government agencies. Clarity of Budget Objectives The clearer the purpose of the budget is in the preparation of the budget, the higher the performance of local government officials and vice versa. The clearer the clarity of the budget goals in the preparation of the budget, the higher the performance of local government agencies in carrying out their duties and responsibilities. Public Accountability influences the performance of local government agencies on. Accountability assessments can be seen from the budgeting process starting from planning, arrangement, until implementation must be reported to the DPRD or the community. The community, in this case has the right to know the budgeting process and can demand accountability for the plan and implementation of the budget. This shows that public accountability has an important role in improving managerial performance of local governments.

\section{BIBLIOGRAPHY}

Anthony, R.N, dan V. Govindarajan. 2001. Management Controls Systems. Boston : Mc Graw-Hill Co.

Audit Board of the Republic of Indonesia (BPK RI). (www.bpk.go.id).

Baird, M., (1998). The role of evaluation. In: Mackay, K. (Ed.), Public Sector Performance — the Critical Role of Evaluation, Selected Proceedings from a World Bank Seminar. World Bank Operations Evaluation Department, Evaluation Capacity Development, Washington DC, April, pp. 7-12.

Brownell, Peter. 1982. Participation in Budgeting Process: When it Works and When it Doesn't, Journal of Accounting Literature, Vol.1, pp. 124-153.

Cecilia Lelly Kewo (2014). The Effect of Participative Budgeting, Budget Goal Clarity and Internal Control Implementation on Managerial Performance. Research Journal of Finance and Accounting. ISSN 2222-1697 (Paper) ISSN 2222-2847 (Online)Vol.5, No.12, 2014.

Chandler, Ralph C, and Plano, Jack C. (1982). Public Administration Dictionary. New York: John Wiley \& Sons.

Cherrington, David J. 1995.The Management of Human Resources (4th Edition). New New Jersey: Prentice Hall Inc. 
Dubnick, Melvin J., and Barbara S. Romzek (1993).'Accountability and the Centrality of Expectations in American Public Administration'. Research in Public Administration. Volume 2: 37 78.

Hansen-Mowen, 2004, "Issue 7, Book 1 Management Accounting", Jakarta: Salemba Empat.

Hansen, D.R and Mowen, M.M (2005), Environmental Cost Management, Management Accounting, ThomsonSouth-Western, Mason, OH, pp. 490-526.

Hatry, H. P. (1999). Performance Measurement: Getting Results. Washington, D.C.: The Urban Institution Press.

Hossein Etemadi and Saeed Sirghani (2016). The effect of the budget slack creation and budget internal control by managers on maximization of utility function in budgetary participation. International Journal of Finance and Managerial Accounting, Vol.1, No.2, Summer 2016.

Herzberg, 1959.The Motivation to Work. New York: John Willey and Sons.

Indra Bastian. 2006. Public Sector Accounting, An Introduction. Jakarta: Earlangga.।

Kenis, I. 1979. Effects on Budgetary Goal Characteristic on Managerial Attitudes and Performance. The Accounting Review LIV (4). 707-721.

Locke, E. A. 1968. Toward A Theory of Task Motivation and Incentives. American Institutes of Research. No. 16, Hal: 3:157-89.

Mardiasmo. 2002. Public Sector Accounting, Edition Two. Yogyakarta: Andi Publisher. 2004. Regional Autonomy and Financial Management. Yogyakarta. Andi.

Mardiasmo, 2004, Public Sector Accounting (second edition). Yogyakarta.

Mahoney, T.A., Jerdee, T.H., and Carrol, S.J. 1963. Development of Managerial Performance: A Research Approach. Cincinati: South-Western Publishing Company.

Mahsun, Sulistiyowati, and Andre. 2006. Public sector accounting. Yogyakarta: Faculty of Economics UGM.

Milani, K. 1975. The Realationship of Participation in Budget-settingto Industrial Supervisor Performance and Attitude: A Field Study. The Accounting Review. April:274-284.

Mulyadi and Setyawan. 2001. Management Planning and Control Systems. Jakarta: Salemba Empat.

Nurlis, 2018. The Effect of The Government Accounting Standards Implementation and Apparatus Competency on the Quality of the Local Government Financial Reporting (Case Study at Klaten District Government). Research Journal of Finance and Accounting ISSN 2222-1697 (Paper) ISSN 22222847. Vol.9, No.8, 2018.

Peters, B. G. 2010. Te Politics of Bureaucracy: An Introduction to Comparative Public Administration 6th edition. Routledge. New York, NY.

Pollitt, C. 2008. Performance Blight and the Tyranny of Light? Accountability in Advanced Performance Measurement Regime. Paper dipresentasikan pada the Kettering Foundation Symposium on accountability, May 22-23, 2008 di Dayton, Ohio.

Pornpan Damrongsukniwat, Danuja Kunpanitchakit, and Supol Durongwatana (2015). The Measurements of Budgetary Slack: The Empirical Evidence of Listed Companies in Thailand. Journal of Economics, Business and Management, Vol. 3, No. 2, February 2015.

Republic of Indonesia. 2006. Permendagri Number 13 of 2006 concerning Guidelines for Regional Financial Management. Jakarta: State Secretariat. 
Republic of Indonesia, Law Number 17 of 2003 concerning State Finance.

Setiyawati, Hari., “The effect of Internal Accountants' Competence, Managers' Commitment to Organizations and the Implementation of the Internal Control System on the Quality of Financial Reporting", International Journal of Business and Management Invention, www.ijbmi.org, Volume 2 Issue 11, PP.19-27, November 2013.

Schillemans, T. 2011. Does horizontal accountability work? evaluating potential remedies for the accountability deficit of agencies. Administration and Society 43 (4): 387-416. https://doi.org/10.1177/0095399711412931.

Shah, Anwar and Chunli Shen. 2007. Citizen-Centric Performance Budgeting at the Local Level. Public Sector and Governance and Accountability Series: Local Budgeting. World Bank.

Sheehan, R. M. (1996). Mission accomplishment as philanthropic organization effectiveness: Key findings from the excellence in philanthropy project. Nonprofit and Voluntary Sector Quarterly, 25(1), 110-123.

Shields, J.F and Shields, M.D. 1998. Antecedents of Participate Budgeting. Accounting, Organization, and Society. Vol.23. No.1. Pp.49- 76.

Sri Sundari, Abdul Hamid Habbe dan Mediaty (2016). The Relation among Budgetary Participation an.d Budgetary Slack with Organizational Commitment and Leadership Style as Moderating Variable. IOSR Journal of Business and Management (IOSR-JBM) e-ISSN: 2278-487X, p-ISSN: 2319-7668. Volume 18, Issue 10. Ver. VII (October. 2016), PP 28-36 www.iosrjournals.org.

Tanjung, Abdul Hafidz., "Accounting for Accrual Based Local Governments Appropriate PP Approach. No.71/ 2010 ". Alfabeta, Bandung, 2013. 